\title{
Height prediction equations using diameter and stand density measures
}

\author{
by Christie Staudhammer ${ }^{1}$ and Valerie LeMay ${ }^{2}$
}

\begin{abstract}
Height equations for western hemlock (Tsuga heterophylla (Raf.) Sarg.), western red cedar (Thuja plicata Donn), Douglas-fir (Pseudotsuga menziesii (Mirb.) Franco), and alder (Alnus rubra Bong. and Alnus tenuifolia Nutt.) were fitted using dbh as the predictor variable. A simple, non-linear equation gave very similar results to the Weibull distribution, except for hemlock, which was better modelled using the more flexible Weibull distribution function. Introducing stand density variables into the base equations resulted in increased accuracy for predicting heights of alder. Smaller improvements were found for Douglas-fir, cedar, and hemlock.
\end{abstract}

Key words: estimating height, Coastal BC, Weibull estimation, stand density measures

Huit équations ont été ajustées en utilisant le dhp en tant que variable de prédiction pour la pruche de l'ouest (Tsuga heterophylla (Raf.) Sarg.), le cèdre rouge de l'ouest (Thuja plicata Donn), le sapin Douglas (Pseudotsuga menziesii (Mirb.) Franco) et l'aulne (Alnus rubra Bong et Alnus tenuifolia Nutt.) Une équation simple, non linéaire a donné des résultats très semblables à la distribution de Weibull, sauf pour la pruche, qui a été mieux modélisée par la fonction de distribution plus flexible de Weibull. L'introduction des variables de densité de peuplement dans les équations de base a entraîné un accroissement de la précision dans le cas de la prédiction de la hauteur des aulnes. De plus petites améliorations ont été retrouvées dans le cas du sapin Douglas, du cèdre et de la pruche.

Mots-clés: estimation de la hauteur, côte de la C.-B., estimation de Weibull, mesures de la densité du peuplement

\section{Introduction}

Tree height information is used to estimate tree volumes, site index, and predict tree and stand development. Devices which use ultrasound or laser pulses to measure distances have reduced the time needed to measure tree heights, but measuring heights still requires more time than measuring the diameter outside bark at breast height (1.3 m above ground; dbh). For this reason, often only a subset of trees with measured dbhs is also measured for height. For the remaining trees, accurate height estimates are needed. Often dbh alone is used to estimate these tree heights. However, more accurate predictions can be obtained by including other tree and stand variables such as age, site index, stand basal area, and species composition (Curtis 1967, Larsen and Hann 1987, and Wang and Hann 1988, Huang and Titus 1994). Issues that arise in estimating tree heights include which model to use, which variables to include along with dbh, and how to incorporate these additional variables.

In the Coastal Western Hemlock (CWH) biogeoclimatic (BEC) zone of southwestern British Columbia (BC), the maximum tree size for most species is quite large, reaching over $1 \mathrm{~m}$ in $\mathrm{dbh}$ and over $50 \mathrm{~m}$ in height. Height estimation can be more difficult because this very large height range is commonly associated with a wider range in tree form. The region encompasses low to middle elevations west of the Coastal Mountains and is the wettest BEC zone in BC, receiving 1000 to $4000 \mathrm{~mm}$ of precipitation annually (Meidinger and Pojar 1991). The climate is cool mesothermal, with a mean annual temperature of

\footnotetext{
${ }^{1}$ Department of Forest Resources Management, University of British Columbia, 2045-2424 Main Mall, Vancouver, British Columbia V6T 1Z4. E-mail: kovacs@interchange.ubc.ca

${ }^{2}$ Department of Forest Resources Management, University of British Columbia, 2045-2424 Main Mall, Vancouver, British Columbia V6T 1 Z4. E-mail: lemay@interchange.ubc.ca. Author to whom all correspondence should be addressed.
}

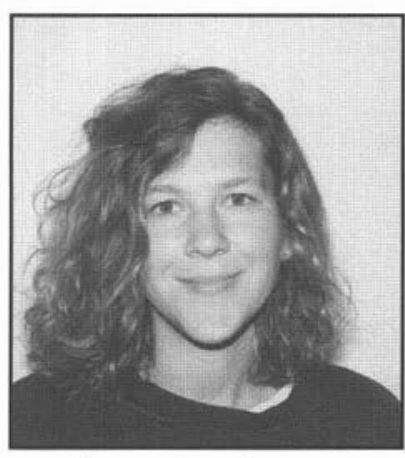

Christie Staudhammer

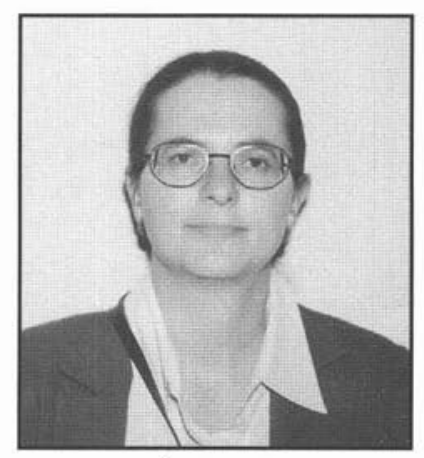

Valerie LeMay $8^{\circ} \mathrm{C}$ and mild winters. The most common species in the forest cover are Douglas-fir (Pseudotsuga menziesii (Mirb.) Franco), western hemlock (Tsuga heterophylla (Raf.) Sarg.), western red cedar (Thuja plicata Donn), amabilis fir (Abies amabilis (Dougl.) Forbes), and Sitka spruce (Picea sitchensis (Bong.) Carr.).

As part of a recent forest inventory of the University of British Columbia Malcolm Knapp Research Forest (MKRF), height prediction equations were developed for many of the species common to the CWH zone. Several models to predict height from dbh were selected from the literature as candidate models (e.g., Curtis 1967, Vestjordet 1977, and Yang et al. 1978, Arabatzis and Burkhart 1992). The base models using dbh as a predictor variable were then modified to include stand variables using a parameter prediction approach (Clutter et al. 1983), and by adding the stand variables to the model directly. Height prediction models using dbh alone, and dbh together with stand variables as predictors are presented in this paper, along with a discussion of the merits of including the stand variables, and a comparison of the two approaches for adding these variables. 


\begin{tabular}{|c|c|c|c|c|}
\hline $\begin{array}{l}\text { Species } \\
\text { Label }\end{array}$ & $\begin{array}{l}\text { Western Red } \\
\text { Cedar (Thuja } \\
\text { plicata Donn) } \\
\text { CW }\end{array}$ & $\begin{array}{c}\text { Alder (Alnus } \\
\text { rubra } \text { Bong. and } \\
\text { A. tenuifolia } \text { Nutt.) } \\
\text { D }\end{array}$ & $\begin{array}{c}\text { Douglas Fir } \\
\text { (Pseudotsuga menzeisii } \\
\text { (Mirb.) Franco) } \\
\text { F }\end{array}$ & $\begin{array}{c}\text { Western Hemlock } \\
\text { (Tsuga heterophylla } \\
\text { (Raf.) Sarg.) } \\
\text { HW }\end{array}$ \\
\hline Number of trees & 210 & 28 & 230 & 261 \\
\hline $\begin{array}{l}\text { Dbh }(\mathrm{cm}) \\
\text { Mean } \\
\text { Minimum } \\
\text { Maximum } \\
\text { Std. Dev. }\end{array}$ & $\begin{array}{r}42.4 \\
2.7 \\
141.0 \\
23.8\end{array}$ & $\begin{array}{r}13.5 \\
2.3 \\
62.3 \\
13.0\end{array}$ & $\begin{array}{r}42.3 \\
2.0 \\
180.5 \\
33.2\end{array}$ & $\begin{array}{r}32.2 \\
2.0 \\
90.8 \\
17.6\end{array}$ \\
\hline $\begin{array}{l}\text { Height (m) } \\
\text { Mean } \\
\text { Minimum } \\
\text { Maximum } \\
\text { Std. Dev. }\end{array}$ & $\begin{array}{r}23.4 \\
2.8 \\
49.0 \\
9.8\end{array}$ & $\begin{array}{r}12.3 \\
2.1 \\
30.7 \\
8.4\end{array}$ & $\begin{array}{r}26.4 \\
2.0 \\
66.2 \\
15.1\end{array}$ & $\begin{array}{r}24.2 \\
2.5 \\
51.5 \\
11.1\end{array}$ \\
\hline Number of plots & 124 & 16 & 138 & 161 \\
\hline $\begin{array}{l}\text { Stems per ha } \\
\text { Mean } \\
\text { Minimum } \\
\text { Maximum } \\
\text { Std. Dev. }\end{array}$ & $\begin{array}{r}1586 \\
85 \\
19094 \\
2167\end{array}$ & $\begin{array}{r}3371 \\
85 \\
6854 \\
2227\end{array}$ & $\begin{array}{r}1364 \\
55 \\
23899 \\
2014\end{array}$ & $\begin{array}{r}1862 \\
55 \\
35042 \\
2991\end{array}$ \\
\hline $\begin{array}{l}\text { Basal Area per ha } \\
\text { Mean } \\
\text { Minimum } \\
\text { Maximum } \\
\text { Std. Dev. }\end{array}$ & $\begin{array}{r}58.01 \\
3.77 \\
126.00 \\
24.06\end{array}$ & $\begin{array}{r}30.73 \\
3.77 \\
72.00 \\
19.47\end{array}$ & $\begin{array}{r}43.79 \\
2.40 \\
120.00 \\
28.10\end{array}$ & $\begin{array}{r}49.10 \\
2.55 \\
140.00 \\
24.94\end{array}$ \\
\hline $\begin{array}{l}\text { Relative dbh (cm } \\
\text { Mean } \\
\text { Minimum } \\
\text { Maximum } \\
\text { Std. Dev. }\end{array}$ & $\begin{array}{l}0.70 \\
0.05 \\
1.00 \\
0.24\end{array}$ & $\begin{array}{l}0.51 \\
0.12 \\
1.00 \\
0.29\end{array}$ & $\begin{array}{l}0.82 \\
0.12 \\
1.00 \\
0.23\end{array}$ & $\begin{array}{l}0.71 \\
0.05 \\
1.00 \\
0.25\end{array}$ \\
\hline
\end{tabular}

\section{Methods \\ Data Description}

In 1995, sample plot data were collected on the approximately 5000 ha MKRF, using the Ministry of Forests, Vegetation Inventory Sampling Procedures (Resources Inventory Branch 1994) as the basis for plot establishment, plot size, and measurement procedures. Eighty-two clusters of plots were systematically located over the research forest using square spacing. At each grid intersection, a central plot was located, and then additional plot centres were located in each cardinal direction, 25 $\mathrm{m}$ from the main plot centre. If the total basal area of a stand was estimated to be less than $15 \mathrm{~m}^{2} / \mathrm{ha}$, fixed radius plots were used; otherwise, variable radius plots were used. Because plots occurred throughout the whole of the MKRF, the data represent a variety of microsites and growing conditions.

For all trees above $2 \mathrm{~cm} \mathrm{dbh}$, the species, $\mathrm{dbh}(\mathrm{cm})$ and tree class (live or dead, standing or fallen) were obtained. For a subjectively chosen subset of trees, the total height (m), crown class (dominant, codominant, intermediate, or suppressed), and height to live crown $(\mathrm{m})$ were also measured. The 82 clusters yielded 327 plots containing 1832 live trees. Height was measured on 763 trees (42\%) (Table 1). Height prediction models were developed for the four major species found in the MKRF (western red cedar, Douglas-fir, western hemlock, and two alder species (Alnus rubra Bong. and Alnus tenuifolia Nutt.) combined). Models were also fit for other minor species, but are not presented here.
Crown class was considered as a potential variable to improve height prediction, but this measure is often subjective and was measured only on about one third of the trees with measured heights. Since dbh is influenced by stand density, the following plot variables were added to the height estimation model (Table 1):

1. stems per hectare for all species combined (TSTEMSHA); 2. basal area per hectare for all species combined (TBAHA); 3. percent basal area for the species being modelled (PERCENTBA); and

4. relative dbh (i.e., dbh divided by the maximum $\mathrm{dbh}$ for all species; REL_dbh).

All of these measures are easily calculated using forest inventory plot measures. Curtis' (1982) relative density (RD) was initially included, but preliminary results indicated that other measures resulted in higher precision. When more than one species occurred on a plot, the plot contributed height data for both species; therefore, the total number of plots shown in Table 1 is greater than the 327 plots located over the forest.

\section{Selected Models and Analyses}

Selecting models to predict height from dbh was based on a thorough review of many proposed models presented by Huang et al. (1992). Five models were selected based on graphs of height versus dbh.

$$
\text { height }=1.3+A 1 \times \mathrm{A} 2^{d b h} \times d b h^{A 3}+\varepsilon_{1}
$$




$$
\begin{gathered}
\begin{array}{c}
\text { height }=1.3+E 1 \times\left[1-\exp \left(E 2 \times d b h^{E 3}\right)\right]+\varepsilon_{2} \\
\quad(Y a n g \text { et al. } 1978)
\end{array} \\
\text { height }=1.3+\exp \left(F 1+F 2 \times \frac{1}{d b h}\right)+\varepsilon_{3} \text { (Curtis 1967) } \\
(\text { height }-1.3)^{1 / 3}=G 1+G 2 \times \frac{1}{d b h}+\varepsilon_{4}
\end{gathered}
$$

(Vestjordet 1977)

where $\varepsilon_{1}$ to $\varepsilon_{4}$ represent the error terms and $A 1$ to $G 2$ are coefficients to be estimated. Equation [1] is a simple flexible non-linear curve form. Equation [2] is based on the Weibull distribution, where $E 1$ represents an asymptote for maximum height, and $E 2$ and $E 3$ are shape parameters. Equation [3] is an exponential curve, and equation [4] represents a hyperbola. The y-intercept was restricted for all of the selected models to predict a height of $1.3 \mathrm{~m}$ when dbh is zero. Initial analyses indicated that equations [1] and [2] better fit the data; therefore, equations [3] and [4] were removed from further analyses.

The stand density variables were then added into the selected models, following the methods given by Huang and Titus (1994). Two approaches were used to incorporate the stand density measures into the models.

First, the parameter prediction approach (Clutter et al. 1983) was used. For this approach, the parameters of the base models were replaced by functions of the stand density measures. Since this approach may result in a very large model with many coefficients, starting values can be difficult to choose for non-linear least squares regression. For this reason, the parameter prediction method was restricted to a maximum of two variables to predict the parameters. Preliminary results indicated that using stems per ha and basal area per ha combined gave more precise results than using either variable alone. Also, relative dbh gave better results than PERCENTBA. Therefore, parameter prediction models were based on using stems per ha and basal area per ha (equation [1a] using equation [1] as the base model; equation [2a] using equation [2] as the base model), or using relative dbh and the square of relative $\mathrm{dbh}$ (equation [1b], using equation [1] as the base model; equation [2b], using equation [2] as the base model). For both base models, the two stand density variables were incorporated as linear models to predict each of the parameters of the base model.

The other approach to incorporate the stand density measures was to add these directly to the model. More combinations of variables were considered for this approach, since a more parsimonious model is produced than with the parameter prediction approach. Equation [1] was modified to:

$$
\begin{aligned}
& \text { height }=1.3+J 0 \times J 1^{d b h} \times d b h^{J 2} \times T_{S T E M S H A} 3 \\
& \times T B A H A^{J 4}+\varepsilon_{11} \\
& \text { height }=1.3+K 0 \times K 1^{d b h} \times d b h^{K 2} \times R E L \_d b h^{K 3} \\
& +\varepsilon_{12} \\
& \text { height }=1.3+L 0 \times L 1^{d b h} \times d b h^{L 2} \times T S T E M S H A^{L 3} \\
& \times T B A H A^{L 4} \times R E L \_d b h^{L 5}+\varepsilon_{13} \\
& \text { height }=1.3+M 0 \times M 1^{d b h} \times d b h^{M 2} \times T S T E M S H A^{M 3}
\end{aligned}
$$

where $n$ is the number of observations, $y_{\mathrm{i}}$ is the measured height, $\hat{y}_{i}$ is the estimated height, and $\bar{y}$ is the average of the measured heights. The bias and RMSE values were also calculated by dbh class. The RMSE is commonly calculated by dividing by the number of observations minus the number of estimated parameters, in order to obtain an unbiased estimate of the variance of the errors (Judge et al. 1985). However, the number of observations was small for some dbh classes and less than the

$$
\begin{aligned}
& \times \text { TBAHA } A^{M 4} \times R E L \_d b h^{M 5} \\
& \times P E R C E N T B A^{M 6}+\varepsilon_{14}
\end{aligned}
$$

where $J 0$ to $M 6$ are coefficients to be estimated, and $\varepsilon_{11}$ to $\varepsilon_{14}$ are the error terms. Equation [2] was modified to:

$$
\begin{aligned}
\text { height } & =1.3+N 1 \times\left[1-\exp \left(N 2 \times d b h^{N 3} \times T S T E M S H A^{N 4}\right.\right. \\
& \left.\left.\times T B A H A^{N 5}\right)\right]+\varepsilon_{15} \\
\text { height } & =1.3+P 1 \times\left[1-\exp \left(P 2 \times d b h^{P 3} \times R E L \_d b h^{N 4}\right)\right] \\
& +\varepsilon_{16} \\
\text { height } & =1.3+Q 1 \times\left[1-\exp \left(Q 2 \times d b h^{Q 3} \times T S T E M S H A^{Q^{4}}\right.\right. \\
& \left.\left.\times T B A H A^{Q 5} \times R E L \_d b h^{Q 6}\right)\right]+\varepsilon_{17} \\
\text { height } & =1.3+R 1 \times\left[1-\exp \left(R 2 \times d b h^{R 3} \times T S T E M S H A^{R 4}\right.\right. \\
& \left.\left.\times T B A H A^{R 5} \times R E L \_d b h^{R 6} \times P E R C E N T B A^{R 7}\right)\right] \\
& +\varepsilon_{18}
\end{aligned}
$$

where $N 1$ to $R 7$ are coefficients to be estimated, and $\varepsilon_{15}$ to $\varepsilon_{18}$ are the error terms.

All equations were fit by species using the Marquardt method of the SAS non-linear least squares procedure (PROC NLIN; SAS Institute Inc. 1989). All non-linear regression results were check for a global minimum solution by 1) re-running CNLIN using the Gauss-Newton method, and 2) re-runPROC NLIN using different starting values. For the [1] and [2] fitting using PROC NLIN. Following model fitting, plots of residuals versus predicted height were examined for outliers, lack-of-fit, and unequal variance. Normality plots were used to check for normality of residuals.

Models were compared using the R-squared value, average bias (bias), and root mean squared error (RMSE) calculated as:

$$
R-\text { squared }=1-\frac{\sum_{i=1}^{n}\left(y_{i}-\hat{y}_{i}\right)^{2}}{\sum_{i=1}^{n}\left(y_{i}-\bar{y}\right)^{2}}
$$$$
\text { Bias }=\frac{\sum_{i=1}^{n}\left(y_{i}-\hat{y}_{i}\right)}{n}
$$$$
R M S E=\sqrt{\frac{\sum_{i=1}^{n}\left(y_{i}-\hat{y}_{i}\right)^{2}}{n}}
$$ 
number of parameters, and the RMSE was used simply as a descriptive statistic. Therefore, the RMSE was calculated by dividing by the number of observations for consistency. For all models, the data used to fit the models was also used to calculate the fit statistics. No efforts were made to split the data prior to fitting.

\section{Results \\ Dbh Only}

Visual inspections of residual plots showed no obvious lack of fit and little evidence of unequal variances, and the normality probability plots indicated that residuals are approximately normal. As expected, dbh was a significant predictor variable $(\alpha$ $=0.05$ ) for every species.

$\mathrm{R}$-squared values were very similar for equations [1] and [2], ranging from 0.76 for cedar to 0.87 in Douglas-fir (Table 2). Overall biases by species group indicated slight overestimations of heights, ranging from -0.09 to $-0.01 \mathrm{~m}$. Biases were a bit smaller for equation [2] (Weibull function) for all species. The RMSEs ranged from $3.953 \mathrm{~m}$ for alder to 5.517 $\mathrm{m}$ for Douglas-fir, and were also slightly smaller for equation [2]. By dbh class, biases ranged from $-2.64 \mathrm{~m}$ for 60 to $80 \mathrm{~cm}$ dbh Douglas-fir to $2.13 \mathrm{~m}$ for 80 to $100 \mathrm{~cm}$ dbh cedar (Table 3). Biases for equation [2] were less for the smaller dbh classes, but greater for the larger dbh classes compared to equation [1]. RMSE values across the dbh classes ranged from 1.25 $\mathrm{m}$ for hemlock trees less than $10 \mathrm{~cm}$ dbh to $10.27 \mathrm{~m}$ in 80 to $100 \mathrm{~cm}$ dbh Douglas-fir (Table 4); however, RMSEs were similar for both equations over all dbh classes. Overall, the Weibull function was only slightly more accurate than the more simple, flexible non-linear model for all species. Coefficients for the Weibull function are given in Table 5.

\section{Dbh with Stand Density Variables}

The absolute value of the average bias was sometimes a bit larger when stand density variables were added than for the base equation (shaded areas, Table 2), indicating that some lack of fit was introduced by adding the stand density variables. For the three coniferous species, an increase in bias occurred more commonly when equation [1] was the base equation. However, the addition of stand density variables resulted in increased R-square values, and decreased RMSE values for all species and models. For the three coniferous species, the addition of the stand density variables resulted in an approximately $0.3 \mathrm{~m}$ reduction in RMSE. Greater reductions in RMSE occurred for alder.

In terms of RMSE and R-square values, equation [1f] using all four measures of stand density gave the best results for alder. However, alder had a small sample size of 28 trees, which may have affected the results. The reduction in RMSE was from $3.960 \mathrm{~m}$ for equation [1] to $2.081 \mathrm{~m}$ for equation [1f]. Equation [2f] gave similar results, as did the more parsimonious model, equation [2a] (using stems and basal are per ha). Over the limited dbh classes for alder, biases were less than $0.60 \mathrm{~cm}$ for many models, but were higher for equations [1f] and [2f], indicating that a lack of fit may have resulted from introducing all four density measures (Table 3). The RMSEs over the dbh range varied greatly across models, with the lowest values given by equations [1f], [2f], and [2a].

For cedar, equation [1f] (using all four density variables) gave the largest increase in R-square and largest drop in
Table 2. Comparison of models by species. Shaded areas indicate fit statistics that are poorer than the base model ${ }^{3}$.

\begin{tabular}{|c|c|c|c|c|c|}
\hline \multirow[b]{2}{*}{ Model } & & \multicolumn{4}{|c|}{ Species } \\
\hline & & $\mathrm{CW}$ & D & $\mathbf{F}$ & HW \\
\hline 1 & $\begin{array}{l}\text { R-squared } \\
\text { Bias (m) } \\
\text { RMSE (m) }\end{array}$ & $\begin{array}{r}0.757 \\
-0.074 \\
4.797\end{array}$ & $\begin{array}{r}0.769 \\
-0.091 \\
3.960\end{array}$ & $\begin{array}{r}0.866 \\
-0.091 \\
5.517\end{array}$ & $\begin{array}{r}0.810 \\
-0.025 \\
4.813\end{array}$ \\
\hline 1a & $\begin{array}{l}\text { R-squared } \\
\text { Bias } \\
\text { RMSE }\end{array}$ & $\begin{array}{r}0.768 \\
-0.221 \\
4.692\end{array}$ & $\begin{array}{l}0.870 \\
0.173 \\
2.967\end{array}$ & $\begin{array}{r}0.873 \\
-0.353 \\
5.378\end{array}$ & $\begin{array}{r}0.812 \\
-0.348 \\
4.788\end{array}$ \\
\hline $1 b$ & $\begin{array}{l}\text { R-squared } \\
\text { Bias } \\
\text { RMSE }\end{array}$ & $\begin{array}{r}0.803 \\
-0.018 \\
4.325\end{array}$ & $\begin{array}{l}0.808 \\
0.011 \\
3.605\end{array}$ & $\begin{array}{r}0.885 \\
-0.091 \\
5.113\end{array}$ & $\begin{array}{l}0.832 \\
0.165 \\
4.532\end{array}$ \\
\hline $1 \mathrm{c}$ & $\begin{array}{l}\text { R-squared } \\
\text { Bias } \\
\text { RMSE }\end{array}$ & $\begin{array}{r}0.784 \\
-0.048 \\
4.526\end{array}$ & $\begin{array}{l}0.890 \\
0.076 \\
2.736\end{array}$ & $\begin{array}{r}0.881 \\
-0.069 \\
5.206\end{array}$ & $\begin{array}{r}0.828 \\
-0.054 \\
4.587\end{array}$ \\
\hline $1 \mathrm{~d}$ & $\begin{array}{l}\text { R-squared } \\
\text { Bias } \\
\text { RMSE }\end{array}$ & $\begin{array}{r}0.789 \\
-0.049 \\
4.474\end{array}$ & $\begin{array}{r}0.774 \\
-0.067 \\
3.919\end{array}$ & $\begin{array}{r}0.875 \\
-0.088 \\
5.333\end{array}$ & $\begin{array}{r}0.824 \\
-0.029 \\
4.637\end{array}$ \\
\hline $1 \mathrm{e}$ & $\begin{array}{l}\text { R-squared } \\
\text { Bias } \\
\text { RMSE }\end{array}$ & $\begin{array}{r}0.803 \\
-0.024 \\
4.319\end{array}$ & $\begin{array}{l}0.909 \\
0.177 \\
2.480\end{array}$ & $\begin{array}{r}0.882 \\
-0.070 \\
5.178\end{array}$ & $\begin{array}{r}0.832 \\
-0.041 \\
4.536\end{array}$ \\
\hline 1f & $\begin{array}{l}\text { R-squared } \\
\text { Bias } \\
\text { RMSE }\end{array}$ & $\begin{array}{r}0.814 \\
-0.034 \\
4.203\end{array}$ & $\begin{array}{l}0.936 \\
0.127 \\
2.081\end{array}$ & $\begin{array}{r}0.882 \\
-0.069 \\
5.178\end{array}$ & $\begin{array}{r}0.832 \\
-0.039 \\
4.527\end{array}$ \\
\hline 2 & $\begin{array}{l}\text { R-squared } \\
\text { Bias } \\
\text { RMSE }\end{array}$ & $\begin{array}{r}0.761 \\
-0.060 \\
4.764\end{array}$ & $\begin{array}{r}0.770 \\
-0.083 \\
3.953\end{array}$ & $\begin{array}{r}0.866 \\
-0.077 \\
5.505\end{array}$ & $\begin{array}{r}0.811 \\
-0.014 \\
4.806\end{array}$ \\
\hline $2 a$ & $\begin{array}{l}\text { R-squared } \\
\text { Bias } \\
\text { RMSE }\end{array}$ & $\begin{array}{r}0.783 \\
-0.018 \\
4.538\end{array}$ & $\begin{array}{l}0.899 \\
0.003 \\
2.622\end{array}$ & $\begin{array}{r}0.880 \\
-0.069 \\
5.221\end{array}$ & $\begin{array}{l}0.823 \\
0.007 \\
4.652\end{array}$ \\
\hline $2 b$ & $\begin{array}{l}\text { R-squared } \\
\text { Bias } \\
\text { RMSE }\end{array}$ & $\begin{array}{r}0.804 \\
-0.033 \\
4.308\end{array}$ & $\begin{array}{l}0.803 \\
0.061 \\
3.659\end{array}$ & $\begin{array}{r}0.883 \\
-0.052 \\
5.150\end{array}$ & $\begin{array}{l}0.839 \\
0.008 \\
4.438\end{array}$ \\
\hline $2 c$ & $\begin{array}{l}\text { R-squared } \\
\text { Bias } \\
\text { RMSE }\end{array}$ & $\begin{array}{r}0.784 \\
-0.036 \\
4.527\end{array}$ & $\begin{array}{l}0.885 \\
0.148 \\
2.798\end{array}$ & $\begin{array}{r}0.880 \\
-0.046 \\
5.210\end{array}$ & $\begin{array}{r}0.833 \\
-0.008 \\
4.522\end{array}$ \\
\hline $2 d$ & $\begin{array}{l}\text { R-squared } \\
\text { Bias } \\
\text { RMSE }\end{array}$ & $\begin{array}{r}0.783 \\
-0.053 \\
4.535\end{array}$ & $\begin{array}{r}0.771 \\
-0.076 \\
3.944\end{array}$ & $\begin{array}{r}0.873 \\
-0.089 \\
5.369\end{array}$ & $\begin{array}{r}0.823 \\
-0.025 \\
4.651\end{array}$ \\
\hline $2 e$ & $\begin{array}{l}\text { R-squared } \\
\text { Bias } \\
\text { RMSE }\end{array}$ & $\begin{array}{r}0.795 \\
-0.032 \\
4.405\end{array}$ & $\begin{array}{l}0.904 \\
0.351 \\
2.554\end{array}$ & $\begin{array}{r}0.881 \\
-0.053 \\
5.200\end{array}$ & $\begin{array}{r}0.834 \\
-0.012 \\
4.506\end{array}$ \\
\hline $2 \mathrm{f}$ & $\begin{array}{l}\text { R-squared } \\
\text { Bias } \\
\text { RMSE }\end{array}$ & $\begin{array}{r}0.805 \\
-0.047 \\
4.306\end{array}$ & $\begin{array}{l}0.928 \\
0.232 \\
2.203\end{array}$ & $\begin{array}{r}0.881 \\
-0.053 \\
5.199\end{array}$ & $\begin{array}{l}0.835 \\
0.000 \\
4.492\end{array}$ \\
\hline
\end{tabular}

${ }^{3} R-$ squared $=1-\sum_{i=1}^{n}\left(y_{i}-\hat{y}_{i}\right)^{2} / \sum_{i=1}^{n}\left(y_{i}-\bar{y}\right)^{2}$, where $y_{\mathrm{i}}$ is the measured

height; $\hat{y}_{i}$ is the estimated height; $\bar{y}$ is the average height; and $n$ is the number of trees;

$$
\text { Bias }=\sum_{i=1}^{n}\left(y_{i}-\hat{y}_{i}\right) / n ; R M S E=\sqrt{\sum_{i=1}^{n}\left(y_{i}-\hat{y}_{i}\right) / n}
$$

RMSE over the base equations, followed by equations [2b] and [2f] (Table 2). By dbh class, biases were similar over all of the cedar models, with equation [2c] having slightly lower absolute values (Table 3). Equation [1f] resulted in underestimates of heights. The RMSE values for cedar were also similar for all models except for slightly lower values for equations [1f], [2a], and [2b].

For hemlock, all models based on equation [1] gave poorer results than those based on equation [2] (Table 1). Equa- 
Table 3. Comparison of model bias by species and dbh class. Shaded areas indicate a higher absolute value for bias compared to the base model.

\begin{tabular}{|c|c|c|c|c|c|c|c|c|c|c|c|c|c|c|c|c|}
\hline \multirow[b]{2}{*}{ Species } & \multirow{2}{*}{$\begin{array}{l}\text { Dbh } \\
\text { Class } \\
\text { (cm) }\end{array}$} & \multirow{2}{*}{$\begin{array}{c}\begin{array}{c}\text { Number } \\
\text { of } \\
\text { Trees }\end{array} \\
\end{array}$} & \multicolumn{14}{|c|}{ Equation Number } \\
\hline & & & 1 & $1 \mathrm{a}$ & 1b & $1 \mathrm{c}$ & 1d & 1e & If & 2 & $2 a$ & $2 b$ & $2 \mathrm{c}$ & $2 d$ & $2 \mathrm{e}$ & $2 \mathrm{f}$ \\
\hline $\mathrm{CW}$ & $<10$ & 17 & -1.64 & -0.72 & -0.50 & -1.01 & -1.25 & -0.83 & -0.98 & -1.17 & -0.42 & -0.63 & -0.70 & -1.25 & -0.89 & -1.13 \\
\hline $\mathrm{CW}$ & $10-20$ & & -0.93 & -0.34 & -0.87 & -0.72 & -0.83 & -0.63 & -0.76 & -0.74 & -0.52 & -0.96 & -0.68 & -0.92 & -0.83 & -1.01 \\
\hline CW & $20-30$ & 2 & 0.79 & 0.78 & 0.24 & 0.58 & 0.61 & 0.52 & 0.53 & 0.68 & 0.61 & 0.26 & 0.42 & 0.58 & 0.40 & 0.40 \\
\hline $\mathrm{CW}$ & $30-40$ & 34 & 1.68 & 1.22 & 1.32 & 1.26 & 1.36 & 1.16 & 1.23 & 1.45 & 1.06 & 1.40 & 1.14 & 1.41 & 1.22 & 1.30 \\
\hline $\mathrm{CW}$ & $40-60$ & 71 & -0.37 & -0.96 & -0.22 & -0.44 & -0.24 & -0.32 & -0.18 & -0.51 & -0.56 & -0.25 & -0.38 & -0.16 & -0.13 & 0.02 \\
\hline W & $60-80$ & 5 & -0.93 & -1.03 & -0.77 & -0.22 & -0.87 & -0.40 & -0.58 & -0.78 & -0.27 & -0.88 & -0.22 & -0.80 & -0.36 & -0.52 \\
\hline W & $80-100$ & 5 & y & 0.62 & 1.69 & 0.17 & 1.35 & 0.31 & -0.85 & 3 & & 1.61 & 0.72 & 1.28 & 0.33 & -0.44 \\
\hline $\mathrm{CW}$ & $>100$ & 6 & - & 2.30 & 1.22 & 1.15 & 1.64 & 1.35 & 1.82 & 1.95 & 1.51 & 1.84 & 0.64 & 0.45 & -0.35 & -0.36 \\
\hline D & $<18$ & 1 & .28 & 0 & -0.26 & 0.23 & -0.20 & 0.63 & 0.37 & -0.22 & -0.11 & -0.04 & .34 & -0.21 & 91 & 0.54 \\
\hline D & 1 & 8 & & -1.1 & & 0 & & -1.5 & -1.21 & 9 & & 0.08 & 8 & -0.07 & 44 & -1.01 \\
\hline D & $20-8$ & 5 & & & & & & & & & & 2 & & 3 & & 1.30 \\
\hline - & $<$ & 33 & -1.07 & -0.07 & -1.41 & -0.02 & -1.20 & -0.90 & -0.52 & -0 & & -0.77 & & -1.15 & -0.68 & -0.67 \\
\hline $\mathrm{F}$ & $10-20$ & 2 & -0.53 & -0.23 & -0.57 & -0.34 & -0.43 & -0.34 & -0.35 & -0.44 & -0.32 & -0.82 & -0.26 & -0.41 & -0.30 & -0.30 \\
\hline $\mathrm{F}$ & $20-30$ & 4 & 0.84 & 0.90 & 0.89 & 0.73 & 0.84 & 0.78 & 0.76 & 0.80 & 0.87 & 0.62 & 0.63 & 0.76 & 0.65 & 0.63 \\
\hline $\mathrm{F}$ & $30-40$ & & -0.39 & -0.80 & -0.03 & -0.53 & 0.01 & -0.37 & -0.38 & -0.53 & -0.64 & -0.18 & -0.67 & -0.12 & -0.55 & -0.58 \\
\hline  & $40-$ & & $1 ?$ & 0.53 & 157 & 1.18 & 1.27 & 1.16 & 1.19 & 1.21 & 1.02 & 1.54 & 1.10 & 1.20 & 1.11 & 1.14 \\
\hline $\mathrm{F}$ & 6 & & -2 & -3.67 & -2.75 & -2.59 & -2.72 & -2.58 & -2.58 & -2.63 & -2 & -2.52 & -2.46 & -2.60 & -2.42 & -2.42 \\
\hline $\mathrm{F}$ & $80-100$ & & 1 & 0.37 & 047 & 1.96 & 1.25 & 1.7 & 1.77 & 1.68 & 2. & 1.49 & 2.27 & 1.59 & 2.20 & 2.19 \\
\hline $\mathrm{F}$ & $>100$ & 10 & 0.43 & 0.66 & 1.28 & 0.19 & 0.49 & 0.21 & 0.19 & 0.54 & 0.24 & 0.15 & -0.07 & 0.20 & -0.17 & -0.20 \\
\hline $\mathrm{HV}$ & & 3 & -0.6 & -0.5 & -0.68 & 0.81 & -0.6 & -0.73 & -0.6 & -0.48 & 0.00 & -0.28 & -0.24 & -0.60 & -0.34 & -0.21 \\
\hline HW & $10-20$ & 42 & & -0.03 & 0.56 & 0.01 & 0. & 0. & 0. & 0. & & 0.42 & 0. & 0.26 & 0.18 & 0.24 \\
\hline HW & $20-20$ & 41 & 0.65 & 0.18 & 0.59 & 0.43 & 0.28 & 0.28 & 0.25 & 0.54 & 0.28 & -0.06 & 0.22 & 0.23 & 0.18 & 0.13 \\
\hline HW & $30-40$ & 71 & -0.28 & -0.78 & 0.34 & -0.06 & -0.13 & -0.03 & -0.06 & -0.36 & -0.47 & -0.10 & -0.26 & -0.16 & -0.17 & -0.21 \\
\hline HW & $40-60$ & 59 & -0.03 & -0.56 & -0.02 & -0.18 & 0.00 & -0.13 & -0.12 & 0.07 & 0.18 & -0.05 & -0.04 & 0.06 & -0.02 & 0.00 \\
\hline HW & $60-100$ & 17 & 0.28 & 0.50 & -0.36 & 0.48 & 0.05 & 0.24 & 0.29 & 0.28 & 0.53 & 0.33 & 0.62 & -0.01 & 0.32 & 0.36 \\
\hline
\end{tabular}

\begin{tabular}{|c|c|c|c|c|c|c|c|c|c|c|c|c|c|c|c|c|}
\hline \multirow[b]{2}{*}{ Species } & \multirow{2}{*}{$\begin{array}{l}\text { Dbh } \\
\text { Class } \\
\text { (cm) }\end{array}$} & \multirow{2}{*}{$\begin{array}{c}\begin{array}{c}\text { Number } \\
\text { of } \\
\text { Trees }\end{array} \\
\end{array}$} & \multicolumn{14}{|c|}{ Equation Number } \\
\hline & & & 1 & 1a & 1b & 1c & 1d & $1 \mathrm{e}$ & 1f & 2 & $2 a$ & 2b & $2 c$ & 2d & $2 \mathrm{e}$ & $2 f$ \\
\hline$\overline{\mathrm{CW}}$ & $<10$ & 17 & 1.80 & 1.22 & 1.27 & 1.23 & 1.61 & 1.30 & 1.37 & 1.40 & 0.83 & 1.28 & 1.03 & 1.75 & 1.50 & 1.61 \\
\hline $\mathrm{CW}$ & $10-20$ & 24 & 4.09 & 4.10 & 4.26 & 3.97 & 4.08 & 4.10 & 3.91 & 4.07 & 3.98 & 4.05 & 4.01 & 4.14 & 4.21 & 4.03 \\
\hline $\mathrm{CW}$ & $20-30$ & 21 & 4.64 & 4.59 & 4.93 & 4.41 & 4.74 & 4.72 & 4.58 & 4.61 & 4.43 & 4.84 & 4.40 & 4.75 & 4.72 & 4.56 \\
\hline $\mathrm{CW}$ & $30-40$ & 34 & 5.08 & 4.88 & 4.71 & 4.83 & 4.89 & 4.74 & 4.69 & 4.01 & 4.83 & 4.75 & 4.80 & 4.92 & 4.77 & 4.74 \\
\hline CW & $40-60$ & 71 & 4.93 & 4.92 & 4.11 & 4.70 & 4.39 & 4.26 & 4.38 & 4.93 & 4.87 & 4.10 & 4.69 & 4.49 & 4.35 & 4.44 \\
\hline $\mathrm{CW}$ & $60-80$ & 32 & 5.34 & 5.20 & 4.63 & 5.02 & 4.85 & 4.52 & 4.07 & 5.30 & 4.98 & 4.68 & 5.04 & 4.93 & 4.68 & 4.34 \\
\hline $\mathrm{CW}$ & $80-100$ & 5 & 6.74 & 5.79 & 6.60 & 5.12 & 6.48 & 5.47 & 4.23 & 6.83 & 5.30 & 6.54 & 5.77 & 6.58 & 5.89 & 5.03 \\
\hline CW & $>100$ & 6 & 5.43 & 5.59 & 4.12 & 5.61 & 4.84 & 5.16 & 4.80 & 5.41 & 4.25 & 4.24 & 5.28 & 4.71 & 4.97 & 4.67 \\
\hline D & $<10$ & 15 & 3.58 & 2.91 & 3.41 & 2.65 & 3.59 & 2.40 & 1.74 & 3.56 & 2.68 & 3.47 & 2.69 & 3.57 & 2.43 & 1.77 \\
\hline D & $10-20$ & 8 & 4.72 & 1.94 & 4.70 & 2.07 & 4.84 & 2.32 & 2.26 & 4.71 & 1.96 & 4.78 & 2.06 & 4.76 & 2.20 & 2.34 \\
\hline D & $20-80$ & 5 & 3.72 & 4.23 & 1.62 & 3.74 & 3.13 & 2.93 & 2.66 & 3.76 & 3.30 & 1.53 & 3.91 & 3.57 & 3.33 & 3.00 \\
\hline $\mathrm{F}$ & $<10$ & 33 & 1.67 & 1.94 & 2.08 & 1.40 & 1.89 & 1.53 & 1.52 & 1.53 & 1.46 & 2.03 & 1.25 & 1.85 & 1.36 & 1.35 \\
\hline F & $10-20$ & 27 & 3.87 & 3.87 & 3.60 & 4.07 & 4.04 & 4.14 & 4.15 & 3.85 & 4.14 & 3.66 & 4.17 & 4.05 & 4.23 & 4.24 \\
\hline $\mathrm{F}$ & $20-30$ & 41 & 4.52 & 4.37 & 4.06 & 4.21 & 4.61 & 4.32 & 4.30 & 4.51 & 4.15 & 4.22 & 4.20 & 4.60 & 4.28 & 4.25 \\
\hline F & $30-40$ & 30 & 4.41 & 4.34 & 4.54 & 4.03 & 4.23 & 4.01 & 4.01 & 4.42 & 4.08 & 4.48 & 4.02 & 4.24 & 4.00 & 4.00 \\
\hline F & $40-60$ & 43 & 6.82 & 6.53 & 6.68 & 6.68 & 6.86 & 6.68 & 6.70 & 6.79 & 6.58 & 6.79 & 6.69 & 6.82 & 6.69 & 6.71 \\
\hline F & $60-80$ & 30 & 6.46 & 6.50 & 5.52 & 5.67 & 5.87 & 5.45 & 5.46 & 6.45 & 5.62 & 5.51 & 5.65 & 5.94 & 5.51 & 5.52 \\
\hline F & $80-100$ & 16 & 10.24 & 9.84 & 8.67 & 9.76 & 9.20 & 9.57 & 9.54 & 10.27 & 10.09 & 8.67 & 9.84 & 9.55 & 9.75 & 9.72 \\
\hline $\mathrm{F}$ & $>100$ & 10 & 3.90 & 3.49 & 4.39 & 3.21 & 4.03 & 3.22 & 3.20 & 3.89 & 3.01 & 4.17 & 2.91 & 3.87 & 3.01 & 2.99 \\
\hline HW & $<10$ & 31 & 1.33 & 1.28 & 1.34 & 1.43 & 1.56 & 1.55 & 1.54 & 1.25 & 1.19 & 1.47 & 1.28 & 1.71 & 1.46 & 1.48 \\
\hline HW & $10-20$ & 42 & 4.63 & 4.55 & 4.05 & 4.07 & 4.20 & 4.00 & 3.96 & 4.65 & 4.03 & 3.70 & 3.94 & 4.17 & 3.92 & 3.88 \\
\hline HW & $20-20$ & 41 & 5.01 & 4.81 & 4.25 & 4.28 & 4.50 & 4.16 & 4.18 & 4.99 & 4.29 & 4.25 & 4.05 & 4.45 & 4.00 & 4.05 \\
\hline HW & $30-40$ & 71 & 4.38 & 4.47 & 4.55 & 4.50 & 4.60 & 4.60 & 4.58 & 4.38 & 4.46 & 4.49 & 4.53 & 4.55 & 4.55 & 4.54 \\
\hline HW & $40-60$ & 59 & 5.83 & 5.82 & 5.66 & 5.50 & 5.63 & 5.48 & 5.38 & 5.83 & 5.90 & 5.59 & 5.55 & 5.70 & 5.54 & 5.42 \\
\hline HW & $60-100$ & 17 & 6.38 & 6.42 & 5.50 & 6.66 & 5.89 & 6.14 & 6.42 & 6.35 & 6.42 & 5.31 & 6.37 & 6.09 & 6.18 & 6.39 \\
\hline
\end{tabular}

tion [2b] using REL_dbh resulted in the best results, with reasonably low biases and RMSE values over the dbh ranges (Tables 2,3 and 4). No real gain was obtained when other stand density measures were added.

The ranges of $\mathrm{dbh}$ and height values were wider for Douglas-fir, which increased the difficulty in finding an accurate height prediction equation. No improvement was noted in using equations [1f] and [2f] over the simpler equations [1e] and [2e] (Tables 2, 3 and 4). Equation [2b] gave very similar results to [2e] also.

For all species, there was no clear advantage, in terms of higher R-square, lower biases, and lower RMSEs, in using the param- 
Table 5. Estimated parameters for selected equations.

Model Using Dbh Only:

height $=1.3+E 1 ¥\left[1-\exp \left(E 2 \times d b h^{E 3}\right)\right]+\varepsilon_{2}$

\begin{tabular}{lccc}
\hline Species & E1 & E2 & E3 \\
\hline Western red cedar & 39.0002 & -0.02164 & 1.01568 \\
Alder & 26.5495 & -0.03079 & 1.20438 \\
Douglas-fir & 68.6382 & -0.01296 & 0.98848 \\
Western hemlock & 41.4831 & -0.01365 & 1.21692
\end{tabular}

Selected Models Using Stand Density to Predict Parameters, E 1, E 2, and $E$ 3:

\begin{tabular}{lcccr}
\hline Species & $\begin{array}{c}\text { Parameter } \\
\text { predicted }\end{array}$ & Constant & $\begin{array}{c}\text { Slope with } \\
\text { TSTEMSHA }\end{array}$ & $\begin{array}{c}\text { Slope with } \\
\text { TBAHA }\end{array}$ \\
\hline Alder & & & & \\
& E1: & 68.0529 & 0.0192872 & -0.77315 \\
& E2: & -0.00877 & 0.00000044 & -0.00061 \\
& E3: & 0.64991 & -0.00008194 & 0.00554
\end{tabular}

\begin{tabular}{rcccc} 
Species & $\begin{array}{c}\text { Parameter } \\
\text { predicted }\end{array}$ & Constant & $\begin{array}{c}\text { Slope with } \\
\text { REL_dbh }\end{array}$ & $\begin{array}{c}\text { Slope with } \\
\text { REL_dbh2 }\end{array}$ \\
\hline Western red cedar & & & \\
E1: & 59.5789 & 12.5373 & -36.98 \\
E2: & 0.00071 & -0.03818 & 0.1551 \\
Douglas-fir & E3: & 1.6577 & -2.02199 & 1.41599 \\
& E1: & 15.759 & 767.419 & -699.761 \\
Western hemlock & E2: & 0.00025 & -0.00332 & -0.0118 \\
& E1: & 2.07538 & -3.38731 & 2.17848 \\
E2: & -1.25839 & 163.146 & -126.716 \\
E3: & 0.00021 & -0.06091 & 0.05552 \\
& 2.34135 & -4.11239 & 3.31119 \\
\hline
\end{tabular}

eter prediction approach over incorporating the variables directly into the equations (Tables 2, 3, and 4).

Coefficients for the selected equations are given in Table 5 .

\section{Discussion and Conclusions}

Precise height estimates are needed, since height measurements are time consuming even if electronic hypsometers are used. However, precision is poor if only dbh is used to predict height. Because stand density generally has more impact on diameter than on height, the relationship between height and dbh is expected to vary with stand density. Also, measures of density are easily obtained on cluster plots. Therefore, the introduction of these measures was evaluated in order to improve height prediction for four species in the $\mathrm{CWH}$ zone of Coastal BC.

For this study, the simple non-linear equation gave very similar results to that based on the Weibull distribution, except for hemlock, which was better modelled using the more flexible Weibull distribution function. However, the Weibull function ensures that predicted heights will increase with increasing $\mathrm{dbh}$, whereas the simple non-linear model does not. There was no clear choice between the parameter prediction approach to incorporate the stand variables versus adding the variables directly into the equation based on the accuracy of the resulting fit. The parameter prediction approach is more attractive, since the additional variables are used to predict parameters leading to easier model interpretation. However, the parameter prediction method results in a less parsimonious model, particularly if several variables are added to the base equation. For more than two variables, incorporating the variables directly into the model would be preferred.

The introduction of stand density variables resulted in increased accuracy for predicting heights of alder. Alder is shade intolerant, relatively short-lived, and has rapid early height growth (Burns and Honkala 1990), which may explain why stand density resulted in improved height-dbh relationships. Smaller improvements were found for Douglas-fir, cedar, and hemlock. Because cedar and hemlock are both shade tolerant (Burns and Honkala), the stand density variables appeared to have less influence on the height versus dbh relationship. Douglas-fir is shadeintolerant (Burns and Honkala), and an improvement with the addition of stand density variables was expected. However, there was no improvement, perhaps because Douglas-fir tends to be dominant in the stands where it occurs. Larsen and Hann (1987) found similar improvements in using basal area to predict heights for Douglas-fir and hemlock (about a $0.5 \mathrm{~m}$ drop in RMSE). The addition of site variables such as elevation, climate, and soil quality that affect height growth may have led to more accurate height estimates. However, Larsen and Hann found only a very small improvement by adding site index for estimating Douglas-fir heights.

The measures used in this study are easily obtained, but resulted in only small increases in precision for all species except alder. Alternate measures of density or competition may prove to be better at estimating heights regardless of position in the canopy; however, these other measures may increase cost. The introduction of age has been used by some authors, but this is difficult to apply if the stands are not even-aged since ages must be measured on every tree, or at least, on each cohort. In the case of multi-species stands, the site index of the dominant species may improve the height estimation of that species, but may not improve the height estimation of minor species. Another alternative is to use an upper stem measurement (form measure) to improve accuracy. However, since form measures require as much time as measuring height, and are not necessarily as precise, this option is not practical. Since stand density measures are readily available on forest inventory plots, these measures can be incorporated to improve height predictions with little to no additional cost.

\section{References}

Arabatzis, A.A. and H.E. Burkhart. 1992. An evaluation of sampling methods and model forms for estimating height-diameter relationships in loblolly pine plantations. For. Sci. 38: 192-198.

Burns, R.M. and B.H. Honkala (tech. coords.). 1990. Silvics of North America: 1. Conifers; 2. Hardwoods. Agriculture Handbook 654. U.S. Department of Agriculture, Forest Service, Washington, DC. Vol.2. $877 \mathrm{p}$.

Clutter, J.L., J.C. Fortson, L.V. Peinaar, G.H. Brister, and R.L. Bailey. 1983. Timber Management - a quantitative approach. John Wiley and Sons, New York. 333 p.

Curtis, R.O. 1967. Height-diameter and height-diameter-age equations for second-growth Douglas-fir. Forest Science. 13: 365-375. Curtis, R.O. 1982. A simple index of stand density for Douglas-fir. For. Sci. 28: 92-94.

Huang, S., S.J. Titus, and D.P. Wiens. 1992. Comparison of nonlinear height-diameter functions for major Alberta tree species. Can. J. For. Res. 22: 1297-1304.

Huang, S. and S.J. Titus. 1994. An age-independent individual tree height prediction model for boreal spruce-aspen stands in Alberta. Can. J. For. Res. 24: 1295-1301.

Judge, G.C., W.E. Griffiths, R.C. Hill, H. Lutkepohl, and T. Lee. 
1985. The theory and practice of econometrics, $2^{\text {nd }}$. Ed. John Wiley and Sons, Toronto. 1019 p.

Larsen, D.R., and D.W. Hann. 1987. Height-diameter equations for seventeen tree species in southwest Oregon. Forest Research Laboratory, Oregon State University, Corvallis. Res. Pap. 49. 161 p.

Meidinger, D and J. Pojar (eds.). 1991. Ecosystems of British Columbia. Province of British Columbia. Victoria, BC. 330 p.

Resources Inventory Branch. 1994. Vegetation Inventory: Draft procedures for the 1994 pilot projects. Ministry of Forests, Resources Inventory Branch, Victoria, BC. $300+$ p. Plus Appendices.

SAS Institute Inc. 1989. SAS/STAT User Guide, Version 6, Fourth Edition, Volume 2. SAS Institute Inc., Cary, NC. 943 p.
Vestjordet, E. 1977. Diameterfordelinger og hoydekurver for ensaldrede granbestand. (Diameter distribution and height curves for even-aged stands of Norway spruce) Meddr norske Skogfors Ves. 29: 482-557.

Wang, C.H. and D.W. Hann. 1988. Height-diameter equations for sixteen tree species in the central western Willamette valley of Oregon. Forest Research Laboratory Oregon State University, Corvalis. Res. Pap. 51. 7 p.

Yang, R.C., A. Kozak, and J.H.G. Smith. 1978. The potential of Weibull-type functions as flexible growth curves. Can. J. For. Res. 8: 424-431. 